\title{
Characterization and Classification of Soils from Different Topographic Positions under Sugarcane Plantation in South Sulawesi, Indonesia
}

\author{
Risma Neswati, Christianto Lopulisa and Ahmad Faudzan Adzima \\ Department of Soil Science, Faculty of Agriculture, Hasanuddin University, Makassar, South Sulawesi, Indonesia, \\ e-mail:neswati76@gmail.com
}

Received February 26, 2019; Revised April 25 , 2019; Accepted May 6, 2019

\begin{abstract}
The topographic position is among the factors influencing soil formation. This study aimed to characterize and classify the soils used for sugarcane plantation developed in different topographic position. This research was conducted in the sugarcane plantation area of Camming, District of Bone, South Sulawesi, Indonesia, from November 2017 to March 2018. Soil observation was carried out on 3 transects, where each transect consisted of three soil profiles located in different position namely summit, backslope, and valleys. Soil samples from each horizon were analyzed for their physical, chemical and micromorphology characteristics in the laboratory. The soil classification system was done by using soil taxonomy up to subgroups level. Results showed that soil characteristics, i.e. soil depth, cation exchange capacity, and the sum of basic cations were likely to increase in the valley than in the backslope and summit. The primary minerals, mainly quartz, calcite, biotite, opaque, and orthoclase, were found especially in the backslope and valley. The pore types consisted of vugh and packing void pores. Pedofeature type of soil was generally in the form of concretions and nodules that showed the process of oxidation and reduction. The soil type in the study area was classified into Typic Haplustepts and Typic Haplustalfs.
\end{abstract}

Keywords: Soil classification, soil-forming, sugarcane, topography

\begin{abstract}
ABSTRAK
Posisi topografi adalah salah satu faktor yang mempengaruhi pembentukan tanah. Penelitian ini bertujuan untuk mengkarakterisasi dan mengklasifikasikan tanah berbagai posisi topografi di daerah perkebunan tebu. Penelitian ini dilakukan di daerah perkebunan tebu Camming, Kabupaten Bone, Sulawesi Selatan, Indonesia yang dilakukan dari November 2017 sampai Maret 2018. Pengamatan tanah dilakukan pada 3 transek dan setiap transek terdiri dari tiga titik profil yang terletak di posisi yang berbeda, terdiri dari puncak, punggung, dan lembah. Setiap sampel tanah horizon dianalisis di laboratorium untuk mengetahui karakteristik fisik, kimia, dan mikromorfologi. Sistem klasifikasi tanah dilakukan dengan menggunakan taksonomi tanah sampai ke tingkat subgroup. Hasil penelitian menunjukkan bahwa kapasitas tukar kation, kedalaman tanah, dan jumlah basa-basa dapat tukar cenderung meningkat di lembah dibandingkan punggung dan puncak. Mineral primer antaralain kuarsa, kalsit, biotit, opak, dan ortoklas ditemukan terutama di bagian punggung dan lembah. Jenis-jenis pori terdiri dari vugh dan packing void. Jenis pedofeature umumnya berupa konkresi dan nodul yang membuktikan telah terjadi proses oksidasi dan reduksi. Jenis tanah di daerah penelitian diklasifikasikan menjadi Typic Haplustepts dan Typic Haplustalfs.
\end{abstract}

Kata kunci: Klasifikasi tanah, pembentuk tanah, tebu, topografi

\section{INTRODUCTION}

The topography is one of determining factors of soil formation (Jenny 1941; Alijani and Sarmadian 2014; Dessalegn et al. 2014; Lawal et al. 2014) through its roles in water flow, both in the land surface (runoff) and inside the land (infiltration). The

J Trop Soils, Vol. 24, No. 2, 2019: 93-100

ISSN 0852-257X; E-ISSN 2086-6682 topography is a major factor controlling both hydrological and soil processes at the landscape scale. This is well-known that qualitatively of topography, along with parent materials, climate, biota, and time, is one of the fundamental soil-forming factors (Seibert et al. 2007). Besides energy, the position is also an important factor in topography. Wood (1942) divided the topographical position into four parts, which were "waxing slope, free face, debris slope, and pediment." Ruhe (1960) conducted 
some modification and changed the topographical parts into five elements in a fully developed "hillslope," they were "summit, shoulder, backslope, footslope, and toe slope." Conacher and Dalrymple (1977) defined slope as a three-dimensional unit that moved from the summit to the valley related to the interaction between soil material and movement, and the shift and sedimentation of entities by water and gravitation. The differences in soil characteristics associated with landscape position are usually attributed to differences in the runoff, erosion and deposition processes that affect soil genesis (Dengiz et al 2006; Dengiz 2010; Yair 1990; Lark 1999). These processes will cause some differences in characteristics and soil properties as well as the differences in soil types in certain categories. For the regions with oblique and hilly topography, the soil layer will be thinner due to erosion; on the other hand, regions with flat topography will have thicker soil layers due to the sedimentation process. The water flow from the summit to valley regions will bring the materials in the soil and the materials sediment. This process influences the characteristics and soil type, which tend to have a different pattern of formation.

Indonesia is one of the countries with great potential of sugar production. Based on the data acquired from The Directorate General of Indonesian Plantation (2012), the biggest production central of sugarcane in Indonesia was located in the East Java with the total area of 196,391 ha of sugarcane plantation; meanwhile, there was a total of 13,500 ha of sugarcane plantation in South Sulawesi, which spread in various regions and the biggest three sugar factories were owned by PT. Perkebunan Nusantara (PTPN) XIV, which Arasoe, Camming, and Takalar. One of the sugar factories in PTPN XIV that has a unique topographical characteristic, which has never been scientifically studied before was Camming, located in Sub-district Libureng, District of Bone. Topographically, the land is dominated by corrugated with weak undulating characteristics.

The production and quality of sugarcane are greatly influenced by the land quality, superior genetic potential of plants, and the aspect of appropriate land management. The land quality is highly related to land characteristics and climate. Sugarcane plantation in Indonesia is commonly located in regions with moderately dry and dry climates. The sugarcane plantation area in Camming is included into a moderately dry area, which is characterized by consecutive four dry months $\left(<75 \mathrm{~mm} \mathrm{month}^{-1}\right)$. The data information of soil type in the Camming sugarcane plantation based on the reconnaisance map of soil type of South Sulawesi (Lembaga Penelitian Tanah 1968) by scale 1:500,000, it was found that there were three types of soil in Camming area; they were 16\% Grumosol, 7\% Litosol, and $77 \%$ Mediterranean soil of the total plantation area. Mediterranean soil has high base saturation, high number of exchangeable bases, and neutral to moderate alkali $\mathrm{pH}$. Based on the system of soil classification according to soil taxonomy system (2014), the Mediterranean, Grumosol, and Litosol soil match to Alfisol or Inceptisol, Vertisol, and Entisol, respectively. However, its compatibility needs to be further proven by the determination of soil type in the observation unit location of the selected soil into the soil subgroup level. The classification resulted based on soil taxonomy could help the land use planner to determine the most appropriate management for certain types of soil, which was already known by its characteristics and main inhibiting factors; therefore, it would be easier to conduct the optimization of land resources.

Based on the aforementioned explanation, it was important to conduct research that aimed to describe the characteristics and to classify the type of soil in different topographical positions in the area of Camming sugarcane plantation in the District of Bone, South Sulawesi based on the soil taxonomy system in subgroup level.

\section{MATERIALS AND METHODS}

\section{Study Site}

This research was conducted in the area of Camming sugarcane plantation in South Sulawesi, which was carried out from November 2017 to March 2018. This is a humid region with an annual rainfall of $2.000 \mathrm{~mm}$. The region is located at 125 meters above sea level. Geologically, the area was formed from limestone, sandstone, siltstone, and conglomerates. This research area had been used for sugarcane since 1984. Organic matter and fertilizer are commonly applied with the rate of 5 tons organic matter ha $\mathrm{a}^{-1}$ and $300 \mathrm{~kg}$ urea ha ${ }^{-1}, 250$ $\mathrm{kg} \mathrm{SP}-36 \mathrm{ha}^{-1}$ and $150 \mathrm{~kg} \mathrm{KCl} \mathrm{ha-1}$.

\section{Research Methods}

This research applied the descriptive method; the researchers conducted observation and description of 9 soil profiles in three transects. Each transect consisted of three profile points located in various positions, which were summit (PC), backslope $(P G)$, and valley $(L M)$ (see Figure 1). 


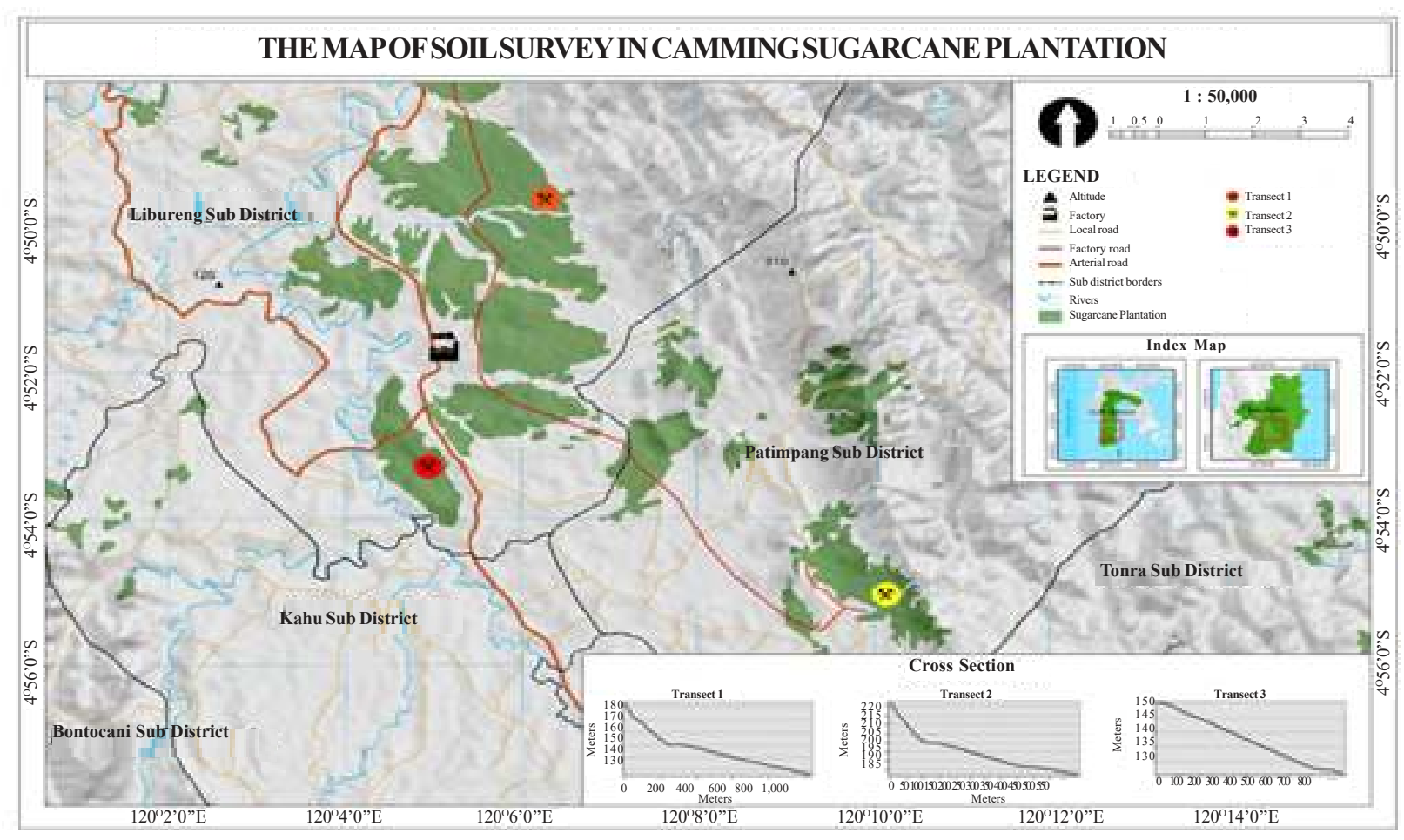

Figure 1. Map of research location

As many as 18 disturbed soil samples were taken from each horizon and were analyzed for its physical properties (soil structure, color, and texture), chemical properties $(\mathrm{pH}$, organic carbon, cation exchange capacity (CEC), and base saturation (BS), and micro-morphological characteristics in the soil laboratory.

\section{Soil Analysis and Classification}

The soil samples were air-dried, crushed and screened using a $2 \mathrm{~mm}$ sieve. The soil texture was determined by the hydrometer method (Bouyoucos 1951) and organic matter by the Walkley-Black digestion method (Nelson and Sommers 1982). Soil reaction $(\mathrm{pH})$ was determined according to the methodology of the Soil Survey Laboratory (1992). Exchangeable cations and cation exchange capacities (CEC) were measured by using the $1 \mathrm{~N}$ $\mathrm{NH}_{4} \mathrm{OAC}(\mathrm{pH} 7)$ method (Soil Survey Laboratory, 1992). The soil micro-morphological analysis was conducted by using a polarized microscope to observe the thin incision made in the soil (thin section). The type and method of soil analysis followed the soil survey laboratory methods and procedures for collecting soil samples (SCS-USDA 1982; Soil Survey Staff 1992). Soil classification according to the system of soil taxonomy to subgroup level was done by applying the $12^{\text {th }}$ edition of the guidebook for soil taxonomy (Soil Survey Staff 2014).

\section{RESULTS AND DISCUSSION}

\section{Physical, Chemical and Morphological Characteristics of Soil}

The depths of soil solum were in the range of 45 to $80 \mathrm{~cm}$ in the summit area, 60 to $80 \mathrm{~cm}$ in the back slope, and 90 to $100 \mathrm{~cm}$ in the valley. The differences in the depth of soil solum were influenced by different topographical positions, where the soils in the summit slope and back slope had eroded and underwent a sedimentation process in the valley area. The soil texture in horizon A and B in the valley part in almost all transects were silty clay loam; meanwhile, in the summit and back slope were silty clay and sandy clay loam, respectively. The difference of texture class was influenced by erosion process through the summit and back slope area, causing the soil particles to be brought and remained in the valley area, therefore clay and silt particle were dominant in the valley area. The soil structure on horizon A and horizon B in the summit area were classified into sub-angular blocky; the soil structure on horizon A and horizon B in the back-slope area were granular, while the soil stucture in the valley area of horizon A was granular and horizon B was sub-angular blocky. The different structure shape of the three topographies was caused by the influence of soil humidity, microorganism activity, plant roots, decaying organic matters, and cations 
trapped in the soil. This was following Oades (1984) that showed that the difference of soil structure was influenced by the humidity and aridity of soil, microorganism activity and roots spread in the soil, cations trapped in the soil colloid, and the decaying organic matters.

The soil color also varied in different topographical position. The value and soil chroma on valley areas were less than three (wet), while in the summit and back slope was less than five (wet). The soil color on horizon A was darker compared to horizon $\mathrm{B}$ on each transect and different topographical position. The difference of color in three topographical positions was caused by the content of organic matters. This corresponded to Sandra et al. (2004) opinion that the cause of different colors on the soil surface was commonly due to the content of organic matter. As the soil contained more organic matters, the soil color would be darker or, on the contrary, as the soil color was lighter, the content of C-organic in the soil was also lower.

The soil bulk density in all observation points was in the range of 1.3 to $1.5 \mathrm{~g} . \mathrm{cm}^{-3}$. The value of bulk density in some profiles showed moderately high value reaching $1.5 \mathrm{~g} . \mathrm{cm}^{-3}$ that could be caused by low content of organic matter in the soil. Soil with high organic matters would have lighter soil bulk density value, and on the contrary, soil with low organic matters would have heavier soil bulk density value. The pressure from heavy machinery used to cultivate the land also causes high soil bulk density in the area of Camming sugarcane plantation. Furthermore, the characteristic of bulk density was also influenced by soil texture. Chaundhari et al. (2013) research showed that the type of soil texture had a significant influence on the value of soil bulk density. The sedimentation activity bringing fine particles also influenced soil solidity. Hardjowigeno (1995) stated that the solider or finer the soil was, the higher soil bulk density, which meant that it would be more difficult for the soil to carry water or to be penetrated by plant roots. Table 1 presented the data of field observation and the analysis result of soil samples.

Soil reaction $\left(\mathrm{pH} \mathrm{H}_{2} \mathrm{O}\right)$ on the research location was in the range of 5.6 to 5.8 . The $\mathrm{pH}$ tended to increase from the morphology located in the upper part to the lower part. The increase was caused by the leaching of bases from the land surface to the lower part of the soil horizon. This corresponded to Sutanto (2003) opinion that ion $\mathrm{Ca}, \mathrm{Mg}, \mathrm{K}$, and $\mathrm{Na}$ in the soil could decrease the concentration of ion $\mathrm{H}^{+}$in the soil solution. Ion $\mathrm{H}^{+}$produced by the leaching process of cations in the soil caused soil acidity. This was also following the results of Nurdin (2012) that $\mathrm{pH}$ value in the upper horizon was commonly lower than the lower horizon as the result of the leaching process under the solum and nutrient absorption by the plants. The leaching process would be more intensive if rain occurred on the flat to sloping regions with good drainage.

Cation exchange capacity (CEC) was commonly lower in horizon A compared to horizon $B$. The value of soil CEC in the valley was higher compared to the ones in the summit and back slope. This was due to the soils in the summit and back slope physiographic position underwent erosion process where the soil particles were brought and sedimented in the valley. Different CEC value was also caused by the effect of giving fertilizer and the effect of the number of clay minerals and organic materials in the soil. According to Hakim (1986), the amount of soil CEC was influenced by the properties and characteristics of the soil itself, which were 1) soil reaction or $\mathrm{pH}, 2$ ) soil texture or amount of clay, 3) type of clay minerals, 4) organic materials, and 5) liming and fertilizing.

The values of base saturation in each observation point showed a moderate to a very high value (BS $>50 \%$ ), which indicated that the soils were still dominated by soil alkaline cations. Tan (1991) stated that base saturation was commonly used as an indication of soil fertility. The highly fertile soil was the one with more than $80 \%$ of base saturation. The moderately fertile soil was the one with between $50 \%$ to $80 \%$ base saturation, and infertile soil was the one with less than $50 \%$ base saturation. This was also consistent with Daru (2011) who indicated that soil with a high degree of base saturation is fertile soil and is rich with nutrients. The high value of exchangeable bases in each soil profile was determined by the position of the profile, which was commonly located in the hillsides and valleys; therefore, sediment could bring bases from the upper hillsides with a higher slope level. It corresponded to Sutanto (2003) who showed that each hillside with a high slope was prone to the transportation of soil formation materials.

The soil organic-C content in horizon A was relatively higher compared to horizon $\mathrm{B}$. Furthermore, the valley topographical position would have relatively higher organic-C content if compared to the summit and back slope. However, the percentage of organic-C was generally in the range of $1.9 \%$ to $2.3 \%$. This difference was caused by the leaching process in the summit and the back slope position was mainly through the mechanisms of surface flow due to the topographical position. Rahayu et al. (2014) showed that soil organic-C 


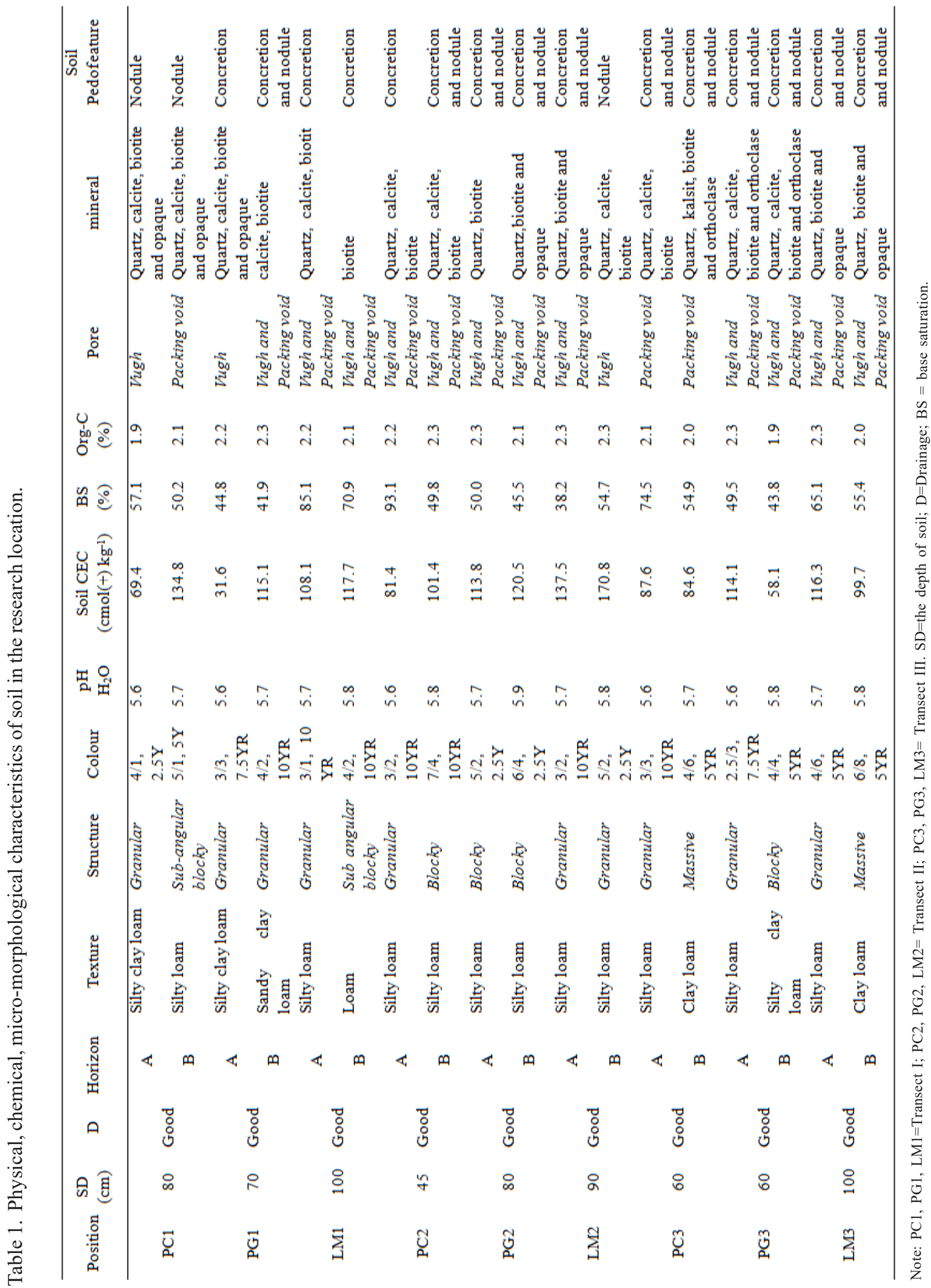




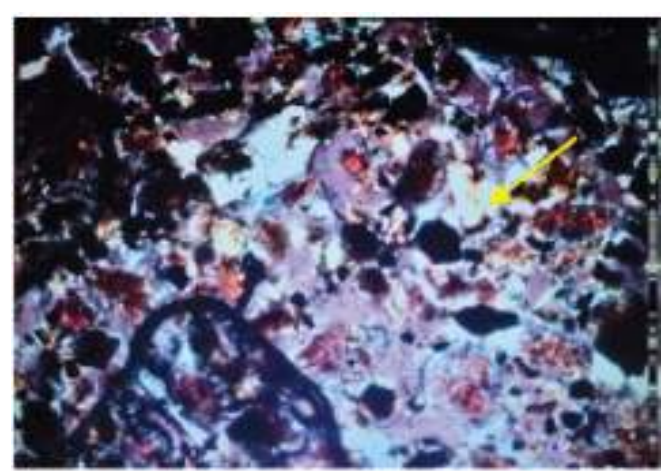

(a)

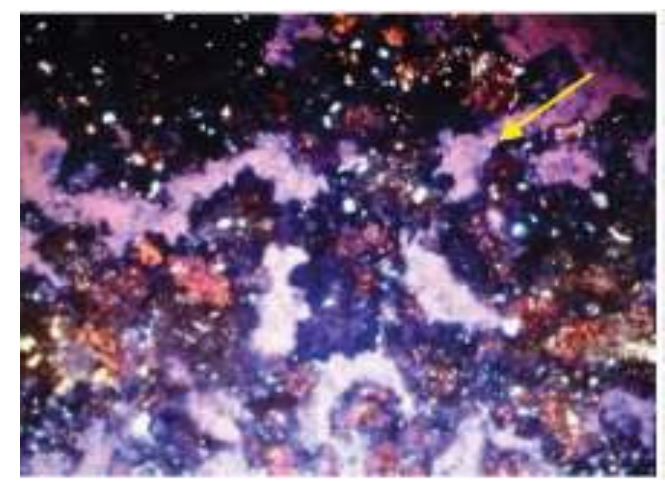

(b)

Figure 2. The appearance of (a) packing void and (b) vugh pores (arrow mark).

content tended to have a similar pattern: the organic material would decrease consecutively as the depth of soil increased. This was mainly caused by the decomposition process of organic materials by microorganisms that was likely to happen in the top layer.

The soil micromorphology analysis using $\mathrm{h}$ polarized microscope successfully detected the type of mineral constituents, pore type, and soil pedofeature type. Generally, the dominant soil minerals in each transect were quartz, calcite, and biotite. The content of soil minerals, especially calcite, was likley to decrease in the sloping area. This was caused by the high intensity of rainfall which caused soil erosion; therefore, soil minerals that were relatively easy to decompose would undergo a faster decomposition process and would be difficult to be found in the valley area.

The dominant pores found in each transect were vugh and packing void. Vugh pore types were mainly found in smooth soil texture (Schaetzl and Anderson 2005). It could be formed due to the sedimentation process of primary particles. Furthermore, soil structure composed of fine particle fraction also influenced the formation of vugh pore. Vugh pore type dominantly formed in soil with finer texture due to the decomposition process that had

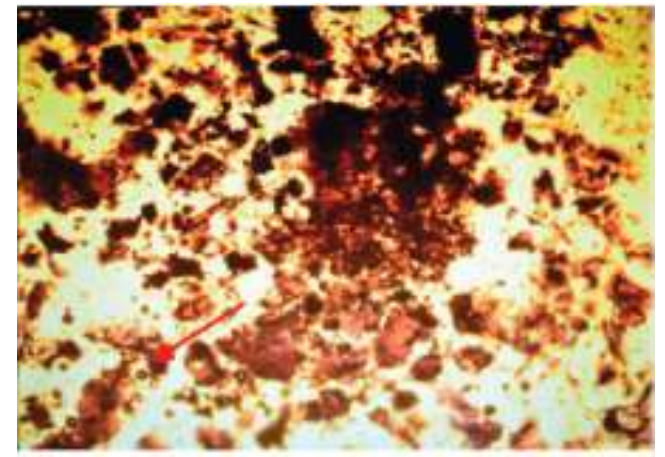

(a)

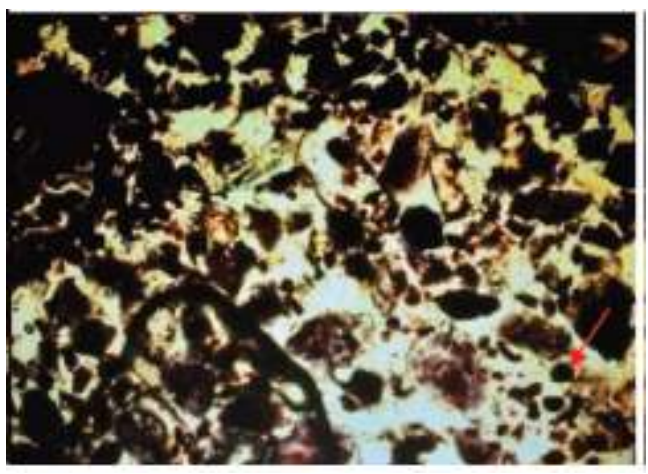

(b)

Figure 3. The appearance of concretions (arrow mark) (a) and nodule (b) on a thin section of soil sample.

further developed. The pores that were not connected to the void walls were included in an irregular shape. The process of mineral decomposition into smaller particles would cover the connected void; therefore, it would further develop into a single void. On the other hand, packing void type was the cavity formed between big-sized particles. The irregular development of pores was caused by the difference of mineral resistance found in each soil layer. This difference formed the cavities (pores) that were significantly different across its minerals. Figure 2 presented the appearance of packing void and vugh pore type found in the research location.

The soil pedo-feature found in each transect was in the form of concretions and nodules, which showed the process of oxidation reduction in the soil. Concretions were formed in the soil from a mineral that underwent decomposition process on its crystal edges and formed oxide layer. The shape, size, and color varied depending on its chemical structures. The appearance of concretions and nodules could be seen in Figure 3.

\section{Soil Classification}

Based on the system of soil taxonomy, soils of Camming sugarcane plantation were classified into 


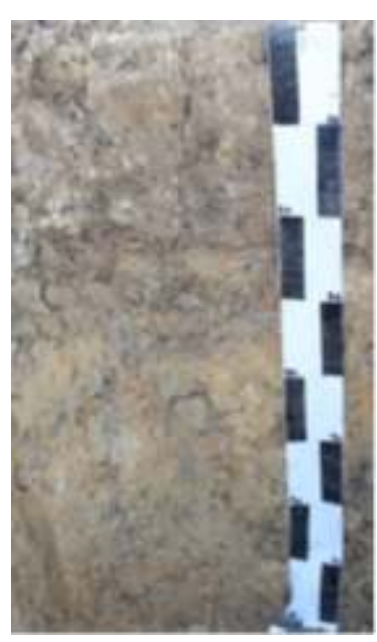

Summit

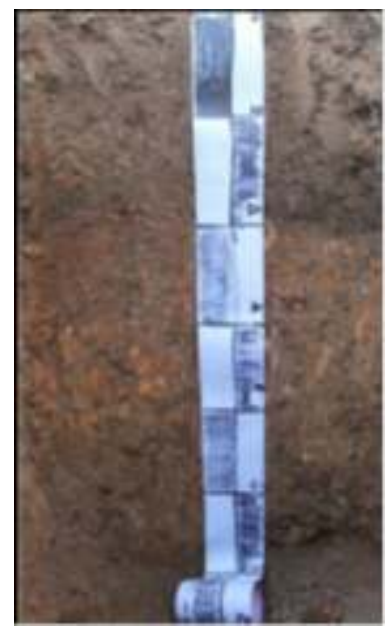

Back-slope

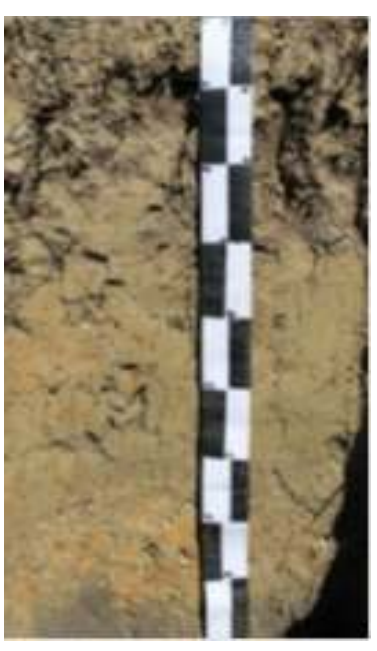

Valley

Figure 4a. Soil profiles were classified as Typic Haplustepts.

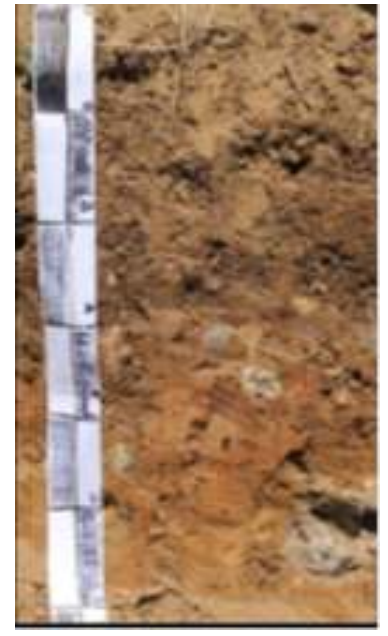

Summit

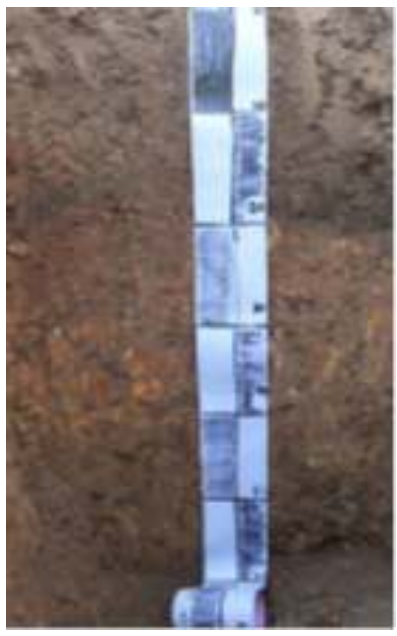

Back-slope

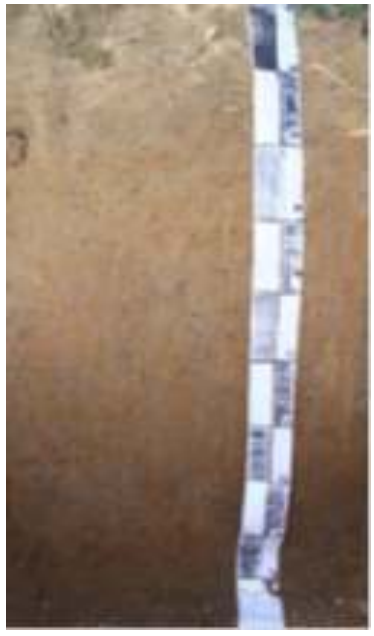

Valley

Figure 4b. Soil profiles were classified as Typic Haplustalfs.

two ordos; namely, Inceptisols and Alfisols. In the subgroup level, they were further classified into Typic Haplustepts and Typic Haplustalfs. Typic Haplustepts soil (Figure 4a) was found in summit, backslope, and valley regions with sandstone (arenite) as its parent rock. This soil commonly had the recent geomorphological surface, therefore the formation had not developed further. The soil texture was commonly silty clay loam, silty clay, sandy clay loam, and clay. The depth of soil was quite shallow to medium with good drainage. The soil $\mathrm{pH}$ was quite acidic; the cation exchange capacity was low to medium with high base saturation. These data confirmed Nurdin (2012) who also found that Haplustepts commonly had clayey texture, acidic to slightly alkaline, moderate nutrient content and reserves, and medium to high cation exchange capacity.
Typic Haplustalfs (Figure 4b) was found in summit, back-slope, and valley regions. This soil is on the slope of $8 \%$ to $15 \%$, and originated from metamorphic rocks. This soil was characterized by its argillic horizon $(\boldsymbol{B} t)$, y clay loam and silty clay loam in texture. This shallow to medium soils had a good drainage. The soil reaction was quite acidic; low to medium cation exchange capacity, yet high base saturation.

\section{CONCLUSIONS}

Soils in some selected profiles in the area of Camming sugarcane plantation in South Sulawesi was formed due to the influences of topographic position, rainfall, and the primary soil materials with characteristics such as soil solum, cation exchange capacity, base saturation, and the primary minerals 
from the sand fraction which were likely to be different on each topographic position in the summit, back, and valley. The types of pores consisted of vugh and packing void pores; and the pedo-feature type of soil was generally in the form of concretions and nodules.

There were two types of soils (sub group) in some selected profiles in the area of Camming sugarcane plantation in South Sulawesi, which were Typic Haplustepts and Typic Haplustalfs that found in the physiographic position of summit, back, and valley regions with slope ranged from $8 \%$ to $15 \%$.

\section{ACKNOWLEDGEMENTS}

The authors deeply thankful to the Department of Soil Science, Faculty of Agriculture, Hasanuddin University and PTPN XIV, Camming Sugar Plantation, District of Bone, South Sulawesi, for providing data, and other supporting facilities for this study.

\section{REFERENCES}

Alijani Z and F Sarmadian. 2014. The Role of Topography in Changing of Soil Carbonate Content. India J Sci Res 6: 263-271.

Bouyoucos, G. J. 1951. A calibration of the hydrometer for making mechanical analysis of soils. Agron $J$ 43:9-11.

Chaundhari PR, DV Ahire, VD Ahire, M Chkravarty and S Maity. 2013. Soil Bulk Density as Related to Soil Texture, Organic Matter and Available Total Nutrients of Coimbatore Soil. Int J Sci Res Pub 3: 1-8.

Conacher AJ and JB Dalrymple. 1977. The Nine Unit Landsurface Model: An Approach to Pedogeomorphic Research. Geoderma 18: 1-154.

Daru M. 2011. Analisis Kesesuaian Lahan dan Evaluasi Jenis Tanah dalam Budidaya Tanaman Tebu untuk Pengembangan Daerah Kabupaten Tegal. J Sains Tehnol 13: 116-123. (in Indonesian).

Dengiz O, C Göl, S Karaca and M Yüksel. 2006. Effects of different landscape position and parent material on soil variability and land use in both sides of Acicay River-Çankýrý. International Soil Meeting on Soil Sustaining Life on Earth, Managing Soil and Technology Proceedings II. Sanlýurfa Turkey. Pp. 745-751.

Dengiz O. 2010. Morphology, Physico-Chemical Properties and Classification of Soils on Terraces of the Tigris River in the South-east Anatolia Region of Turkey. $J$ Agric Sci 16: 205-212.

Dessalegn D, SH Beyene, N Ram, F Walley and TS Gala. 2014. Effects of topography and land use on soil characteristics along the toposequence of Ele watershed in southern Ethiopia. Catena 115: 47-54.

Hardjowigeno S. 1995. Ilmu Tanah. Akademika Pressindo. Jakarta. (in Indonesian)
Jenny H. 1941. Factors of Soil Formation, A System of Quantitative Pedology. McGraw- Hill, New York.

Lark RM. 1999. Soil-landform relationships at withinfield scales: An investigation using continuous classification. Geoderma 92: 141-165.

Lembaga Penelitian Tanah. 1968. Peta Tanah Tinjau Propinsi Sulawesi Selatan skala 1:500.000. Bogor. (in Indonesian).

Lawal BA, PA Tsado, PC Eze, KK Idefoh, AA Zaki and S Kolawole. 2014. Effect of Slope Positions on some Properties of Soils under a Tectona grandis Plantation in Minna, Southern Guinea Savanna of Nigeria. Int J Res in Agric Forestry 1: 37-43.

Nelson DW and LE Sommers. 1982. Total carbon, organic carbon and organic matter. In: LA Page, RH Miller and DR Keeney (eds). Methods of Soil Analysis, Part 2. Chemical and microbiological methods $\left(2^{\text {nd }}\right.$ ed). American Society of Agronomy, Madison, WI, pp. 539-579.

Nurdin. 2012. Morfologi, Sifat Fisik dan Kimia Tanah Inceptisols dari Bahan Lakustrin PaguyamanGorontalo Kaitannya dengan Pengelolaan Tanah. JATT 1: 13-22. (in Indonesian).

Oades JM. 1984. Soil Organic Matter and Structural Stability: Mechanisms and Implications for Management. Plant Soil 76: 319-337.

Rahayu A, RU Sri and ML Rayes. 2014. Karakteristik dan Klasifikasi Tanah pada Lahan Kering dan Lahan yang di Sawahkan di Kecamatan Perak Kabupaten Jombang. J Tanah dan Sumberdaya Lahan. 1: 7787. (in Indonesian).

Ruhe RV. 1960. Elements of The Soil Landscape. Trans. $7^{\text {th }}$ Int. Congress Soil Sci., Madison, Wisc 4: 165-170.

Sandra S, H Knicker and KK Ingrid. 2004. Soil Organic Matter Composition and Soil Lightness. J Nutr Soil Sci 167: 545-555.

Schaetzl R and S Anderson. 2005. Soils, Genesis and Geomorphology. Cambridge University Press. New York.

SCS-USDA. 1982. Soil Survey Laboratory Methods and Procedures for Collecting Soil Samples. USDA Soil Survey Invest.

Seibert J, J Stendahl and R Sorensen. 2007. Topographical influences on soil properties in boreal forests. Geoderma 141: 139-148.

Soil Survey Staff. 1992. Procedures for collecting soil samples and methods of analysis for soil survey. Soil Surv. Invest. Rep. I. U.S. Gov. Print. Office, Washington D.C. USA.

Soil Survey Staff. 2014. Keys to Soil Taxonomy. 12 ${ }^{\text {th }}$ Edition. Natural Resources Conservation Services. United States Department of Agriculture.

Sutanto R. 2003. Dasar-Dasar Ilmu Tanah; Konsep dan Kenyataan. Kanisius. Yogyakarta. (in Indonesian)

Tan HK. 1991. Dasar-Dasar Kimia Tanah. Gajah Mada University Press. Jakarta. (in Indonesian).

Wood A. 1942. The Development of Hillside Slopes. Geol Assoc Proc 53: pp.128-138.

Yair A. 1990. The role of topography and surface cover upon soil formation along hill slopes in arid climates. Geomorphology 3: 287-299. 